\title{
An Empirical Analysis of the Effects of Budget Deficits (Total and Primary) and Personal Income Tax Rates on the Ex Post Real Interest Rate Yield on Long-Term U.S. Treasury Bonds
}

\author{
RICHARD J. CEBULA
}

Jacksonville University, Davis College of Business*

\begin{abstract}
This empirical study adopts an open-economy loanable funds model to investigate the impact of post-Bretton Woods U.S. federal government budget deficits and personal income tax rates on the ex post real interest rate yield on thirty-year Treasury bonds. In this study, the budget deficit is measured in two different ways, the total ("unified") budget deficit and the primary deficit (the total/unified deficit minus net interest payments). Two different estimation techniques, autoregressive two stage least squares estimation and the ARCH (Autoregressive Conditional Heteroscedasticity) Method, for the 1973-2016 study period provide evidence that the ex post real interest rate yield on thirty-year Treasury bonds has been an increasing function of both federal budget deficit measures (expressed as a percent of GDP) and the maximum marginal federal personal income tax rate. The estimations all imply that elevating either the total/unified or primary federal budget deficit appears to raise the cost of borrowing in the U.S., whereas reducing the maximum marginal personal income tax rate appears to reduce the cost of borrowing. Given the potential effects of longer-term real interest rates on investment in new plant and equipment and overall economic growth, policy-makers should not overlook these findings.
\end{abstract}

Keywords: ex post real interest rates; thirty-year Treasury bonds; budget deficits; income $\operatorname{tax}$

JEL Classifications: E43; E62; H62F3,F4

\section{Introduction}

The large (by historical standards) size of federal government budget deficits in the U.S. during recent years has attracted increased attention in both the media and the political arena. This is especially the case during the last decade, during which time the total federal deficit

\footnotetext{
* The author is indebted to Jerzy (Jurek) Konieczny, the Editor of Review of Economic Analysis, and to an anonymous referee for very helpful comments and suggestions that improved this paper.

(C) 2019 Richard J. Cebula. Licensed under the Creative Commons Attribution - Noncommercial 3.0 License (http://creativecommons.org/licenses/by-nc/3.0/. Available at http: //rofea.org.
} 
has exceeded one trillion dollars (current) on four different occasions (fiscal years 2009, 2010,2011 , and 2012) and risen to a relative magnitude of as much as $9.8 \%$ of GDP. The latter data is among those shown in column (a) of Table 1, which summarizes, among other things, federal budget data relative to GDP for the period 1968-2016.

Table 1. Budget Deficit as Percent of GDP; Maximum Marginal Personal Income Tax Rate

\begin{tabular}{|l||c|c|c|c|c|}
\hline Year & $\begin{array}{l}\text { Deficit/ } \\
\text { GDP (\%) }\end{array}$ & $\begin{array}{l}\text { Tax Rate } \\
(\%)\end{array}$ & Year & $\begin{array}{l}\text { Deficit/ } \\
\text { GDP (\%) }\end{array}$ & $\begin{array}{l}\text { Tax Rate } \\
\mathbf{( \% )}\end{array}$ \\
\hline \hline 1968 & 2.8 & 70 & 1993 & 2.8 & 39.6 \\
\hline 1969 & -0.3 & 70 & 1994 & 2.8 & 39.6 \\
\hline 1970 & 0.3 & 70 & 1995 & 2.2 & 39.6 \\
\hline 1971 & 2.1 & 70 & 1996 & 1.3 & 39.6 \\
\hline 1972 & 2.1 & 70 & 1997 & 0.3 & 39.6 \\
\hline 1973 & 1.1 & 70 & 1998 & -0.8 & 39.6 \\
\hline 1974 & 0.4 & 70 & 1999 & -1.3 & 39.6 \\
\hline 1975 & 3.3 & 70 & 2000 & -2.3 & 39.6 \\
\hline 1976 & 4.1 & 70 & 2001 & -1.2 & 35 \\
\hline 1977 & 2.6 & 70 & 2002 & 1.5 & 35 \\
\hline 1978 & 2.6 & 70 & 2003 & 3.3 & 35 \\
\hline 1979 & 1.6 & 70 & 2004 & 3.4 & 35 \\
\hline 1980 & 2.6 & 70 & 2005 & 2.5 & 35 \\
\hline 1981 & 2.5 & 69.125 & 2006 & 1.8 & 35 \\
\hline 1982 & 3.9 & 50 & 2007 & 1.1 & 35 \\
\hline 1983 & 5.9 & 50 & 2008 & 3.1 & 35 \\
\hline 1984 & 4.7 & 50 & 2009 & 9.8 & 35 \\
\hline 1985 & 5 & 50 & 2010 & 8.7 & 35 \\
\hline 1986 & 4.9 & 50 & 2011 & 8.5 & 35 \\
\hline 1987 & 3.1 & 38.5 & 2012 & 6.8 & 35 \\
\hline 1988 & 3 & 28 & 2013 & 4.1 & 39.6 \\
\hline 1989 & 2.7 & 28 & 2014 & 2.8 & 39.6 \\
\hline 1990 & 3.7 & 28 & 2015 & 2.5 & 39.6 \\
\hline 1991 & 4.4 & 31 & 2016 & 3.3 & 39.6 \\
\hline 1992 & 4.5 & 31 & & & \\
\hline
\end{tabular}

Sources: Council of Economic Advisors (2018, Table B-18); Federal Reserve Bank of St. Louis (2017). 


\section{CEBULA Budget Deficits, Tax Rates and Ex-Post Real Interest Rate}

At least some significant portion of the concern about these large budget deficits is related to the potential they have to elevate interest rates, especially long-term rates, and thereby reduce investment in new plant and equipment on the one hand and, as a consequence, diminish the rate of real economic growth on the other hand. The impact of federal budget deficits on interest rates in the U.S. has been researched empirically in a number of studies. ${ }^{1}$ Many of these scholarly studies have concluded that, by competing for funds in the financial marketplace, larger budget deficits raise longer-term interest rates, such as those on sevenyear and ten-year U.S. Treasury notes, Moody's Aaa-rated corporate bonds, and Baa-rated corporate bonds; however, budget deficits have typically been found in this research to not influence short-term interest rates, such as Treasury bills. In any event, since private-sector capital formation is presumably more strongly affected by longer-term than by short-term interest rates, it has been argued compellingly in certain studies (Carlson and Spencer, 1975; Ewing and Yanochik, 1999; Cebula, 2014) that budget deficits may lead to "crowding out" by elevating longer-term interest rates.

Interestingly, the principal focus in most of these previous studies has been on the impact of the total budget deficit on nominal private sector or federal sector interest rate yields, although there are a few exceptions, such as Cebula (2014) and Choi and Holmes (2014), where ex post real interest rates are investigated, and other earlier studies such as Al-Saji (1993) and Cebula and Saltz (1998), where ex ante real interest rates are analyzed. However, it is noteworthy that very little emphasis in the scholarly literature published during the last 20 years has been placed on determinants of the ex post real interest rate yield on long-term, i.e., 30 year, U.S. federal debt issues. This void in the contemporary literature is potentially problematic because the ex post real long-term interest rate yield arguably acts much more directly and profoundly to influence investment in new plant and equipment than do nominal interest rates, be they long-term or short-term. Current evidence regarding the impact of budget deficits on the long-term real interest rate yield on Treasury bonds is thus argued in this study to be potentially useful information for policymakers.

Aside from the matter of government budget deficits, a second highly visible federal government policy issue that is of current relevance in the U.S. is the reduction of federal personal income tax rates under the rubric of "tax reform," as illustrated in statutory form in 2017 in the passage of the "Tax Cuts and Jobs Act." Such a tax reduction has been hypothesized to be a potentially significant source of economic stimulus/expansion for the

\footnotetext{
${ }^{1}$ This is especially the case since the mid-1980s, although the issue has received much less attention during the last decade (e.g., Al-Saji, 1993; Cebula, 2013; Cebula, Angjellari-Dajci, and Foley, 2014; Choi and Holmes, 2014; Ewing and Yanochik, 1999; Findlay, 1990; Gale and Orszag, 2003; Gissey, 1999; Hoelscher, 1983, 1986; Johnson, 1992; Ostrosky, 1990; Koch, 1994; Cebula and Saltz, 1998; Swamy, Kolluri, and Singamsetti, 1992; Zahid, 1988)
} 
U.S. economy ${ }^{2}$ while, at least in the short run, leading to increased budget deficits. Moreover, in theory, personal income tax rate changes can generate macroeconomic effects that can alter the market price and interest rate yields on different kinds of bond issues. More specifically, it is hypothesized in this study that the higher the federal income tax rate, e.g., the higher the maximum marginal federal personal income tax rate, the greater the progressivity of the federal income tax rate structure and hence the greater the demand for tax-exempt bonds and the lower the demand for thirty-year Treasury bonds (which are subject to federal income taxation) as investors substitute the tax-exempt issues for the taxable issues, ceteris paribus. The reduced demand for thirty-year Treasuries, lowers their price and raise their yield. Interestingly, the existing scholarly literature has effectively overlooked the potential impact of the federal income tax rate structure on the ex post real interest rate on long-term U.S. Treasury bonds. Accordingly, it would seem useful and relevant to investigate the potential impact of federal personal income tax rate changes on that interest rate yield. For the interested reader, column (b) of Table 1 demonstrates the pattern of the maximum marginal federal personal income tax rate from 1968 through 2016.

Based upon the above observations, the two-fold objective of this empirical study is to provide current insights into the determinants of the ex post real long-term interest rate yield on thirty-year U.S. Treasury bonds. In so doing, the present study seeks to obtain evidence as to (a) whether or not higher federal budget deficits either in the form of the total/unified deficit or the form of the primary budget deficit elevate this interest rate yield and (b) whether or not lower (higher) federal personal income tax rates act to reduce (increase) this interest rate yield. In pursuit of this two-part objective, this study uses annual data for the post-Bretton Woods period from 1973 through 2016 in order to provide insights that are current. Section 2 of this study provides the framework/model that is adopted, whereas Section 3 defines and describes the specific variables in the empirical model (as well as the full model structure). Section 4 provides the empirical results of both (a) autoregressive two-stage least squares (AR/2SLS) estimations and (b) ML_ARCH estimations of the model. Furthermore, the analysis considers two alternative budget deficit measures, the total budget deficit and the primary budget deficit and is thusly distinguished from most previous related studies. Conclusions based on the empirical analysis are found in Section 5 of the study.

\section{The Framework}

Predicated on the studies by Al-Saji (1993), Hoelscher (1986), Koch (1994), and Cebula (2014), a loanable funds model is adopted in in this study. In this context, the ex post real interest rate yield on thirty-year Treasury bonds is, assuming all other bond markets are in equilibrium, determined by:

\footnotetext{
${ }^{2}$ Witness, e.g., the $4.1 \%$ growth rate of real GDP in the second quarter of 2018 in the U.S.
} 
CEBULA Budget Deficits, Tax Rates and Ex-Post Real Interest Rate

$$
D+\Delta(M 2 / Y)+N C I / Y=D E F Y+S
$$

where:

$D=$ private domestic demand for thirty-year U.S. Treasury bonds;

$\Delta(M 2 / Y)=$ the growth in the ratio of the M2 money supply to the GDP level;

$N C I / Y=$ the ratio of net financial capital inflows to the GDP level;

$D E F Y=$ the total ("unified") federal budget deficit, expressed as a percent of GDP;

$S=$ supply of thirty-year U.S. Treasury bonds.

In this framework, it is expected that:

$$
\begin{aligned}
& D=D(E P R T H I R T Y, \text { EPRTHREE, EPRTXFR, TAXRATE, Y }) \\
& +\quad-\quad-\quad- \\
& S=S(E P R T H I R T Y, \text { EPRTHREE }) \\
& +\quad+
\end{aligned}
$$

where:

EPRTHIRTY $=$ the ex post real average interest rate yield on thirty-year Treasury bonds, expressed as a percent per annum;

EPRTHREE $=$ the ex post real average interest rate yield on three-year Treasury notes, expressed as a percent per annum;

$E P R T X F R=$ the ex post real average interest rate yield on high grade municipal bonds, expressed as a percent per annum;

$T A X R A T E=$ the maximum marginal federal personal income tax rate, expressed as a percent;

$Y=$ the annual percentage growth rate of real GDP.

The value of any ex post real interest rate yield in this study is the nominal interest rate yield in question minus the actual inflation rate, $\pi_{\mathrm{t}}$.

According to the specification in this study, the private sector demand for thirty-year U.S. Treasury bonds is an increasing function of EPRTHIRTY, ceteris paribus, since bond buyers would logically prefer a higher real rate of return on their investment. On the other hand, in theory, the issuers of thirty-year U.S. Treasury bonds would issue fewer such bonds in response to a higher EPRTHIRTY, ceteris paribus, since an elevated EPRTHIRTY would increase the debt service costs associated with those issues. Next, the model includes the interest rate yields on two financial instruments as control variables, namely, three-year Treasury notes and high grade municipal bonds. The three-year Treasury note serves as a high-quality, liquid, and relatively short-term financial instrument that that competes in the financial marketplace with thirty-year Treasuries. The high grade municipal bond serves as a 
high-quality but relatively long-term financial instrument involving a variety of maturities and call dates and a maximum maturity of thirty years that also competes in the financial marketplace with thirty-year Treasury issues. Clearly, high grade municipal bonds can potentially be appealing to bond buyers across a variety of personal income tax brackets and economic and financial circumstances, although the higher the personal income tax bracket, the marginally more appealing such bonds are to investors, ceteris paribus; furthermore, it is noteworthy that an estimated 70 percent of municipal bonds are owned by institutions in the U.S. (Madura, 2008; Cicchetti, 2006) and thus are not directly influenced by federal personal income tax rates. In any case, it is hypothesized here that the higher the value of either EPRTHREE or EPRTXFR, the higher the ex post real interest rate yield on thirty-year U.S. Treasury bonds, ceteris paribus. More specifically, the higher the EPRTHREE, the lower the demand for thirty-year Treasuries due to portfolio substitution and hence the lower the price of and the higher the interest rate yield on those Treasury bonds. Similarly, the higher the EPRTXFR, the lower the demand for thirty-year Treasury bonds due to portfolio substitution and thus the lower the price of and the higher the yield on those thirty-year bonds. In other words, these hypothesized interest rate relationships reflect market competition from a relatively shorter term Treasury issue, three-year Treasury notes, and a relatively long-term non-Treasury issue, high grade tax-free municipal bonds, and how that competition affects the real interest rate yield on thirty-year Treasuries through portfolio substitution.

In addition, the higher the maximum marginal federal personal income tax rate, TAXRATE, the greater the demand for tax-exempt bonds among those in the maximum marginal personal income tax bracket per se and the lower their demand for thirty-year Treasuries, as these higher income investors (who constitute roughly 15 percent of the total demand for municipals) substitute tax-exempt bonds for taxable ones in their portfolios, ceteris paribus. ${ }^{3}$ With this resulting lower demand for thirty-year Treasuries, the price of these bonds will decrease and therefore the higher the ex post real interest rate yield on these bonds will be, ceteris paribus. Finally, the greater the percentage growth rate of real GDP, the greater the extent to which the market expects higher interest rates and hence, especially for longer-term bonds, the greater the degree of anticipated interest-rate risk that is associated with longer-term bonds (Madura, 2008, p. 186; Cicchetti, 2006, p. 620). Hence, the greater the growth rate of real GDP, the lower the demand for thirty-year Treasury bonds and hence the lower the price of and the higher the ex post real interest rate yield on thirty-year Treasury bonds, ceteris paribus.

\footnotetext{
${ }^{3}$ The higher the marginal tax rate, the less appealing the taxable thirty-year Treasuries become and the greater the likelihood of purchasing tax-exempt issues in lieu thereof, i.e., substitution is induced.
} 
Substituting equations (2) and (3) into equation (1) and then proceeding to solve for EPRTHIRTY yields:

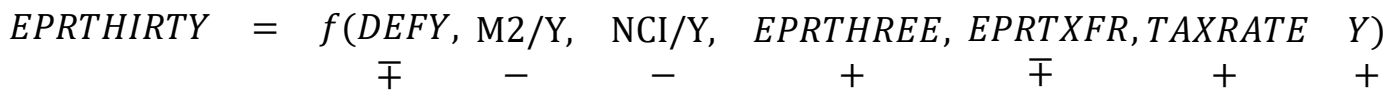

where:

$D E F Y=$ the ratio of the nominal total ("unified") federal budget deficit to the nominal GDP, expressed as a percent;

$(M 2 / Y)=$ the ratio of the nominal M2 money supply to the nominal GDP level, as a percent;

$(N C I / Y)=$ the ratio of nominal net financial capital inflows to the nominal GDP, as a percent.

The first of these hypothesized signs is positive in order to reflect the conventional wisdom that when the government attempts to finance a budget deficit, it forces interest rate yields upwards as it competes with not only the private sector but also the market for tax-free municipal bonds to attract funds, ceteris paribus. The second and third signs reflect, respectively, the conventional wisdom regarding the impacts of a relatively larger money supply and relatively greater capital inflows as they absorb government sector (as well as private sector) debt and thereby diminish upward pressure on interest rates (Hoelscher, 1986). The remaining signs in (4) are predicated upon (2) and (3) above.

\section{Empirical Model and the Data}

Based on the model in equation (4), the following specifications are to be estimated initially, with the autoregressive term being included only in the estimations provided in Section 4a below:

$$
\begin{array}{rcc}
\text { EPRTHIRTY }_{t}= & \propto_{0}+\propto_{1} \text { DEFY }_{t}+\propto_{2}(M 2 / Y)_{t}+\alpha 3(N C I / Y) \mathrm{t}+\propto_{4} \text { EPRTHREE }_{t}+ \\
+ & \propto_{5} \text { EPRTXFR }_{t}+\propto_{6} \operatorname{TAXRATE}_{t}+\propto_{7} Y_{t}+\propto_{8} A R(1)+\varepsilon_{t}
\end{array}
$$

$$
\begin{aligned}
\text { EPRTHIRTY }_{t} & =b_{0}+b_{1} \text { PRIMARYDEFY }_{t}+\mathrm{b}_{2}(M 2 / Y)_{t}+\mathrm{b}_{3}(N C I / Y)_{t}+ \\
& +b_{4} \text { EPRTHRE }_{t}+b_{5} \text { EPRTXFR }_{t}+b_{6} \text { TAXRATE }_{t}+b_{7} Y_{t}+b_{8} A R(1)+\varepsilon_{t}^{*}
\end{aligned}
$$

where:

PRIMARYDEFY= the ratio of the nominal primary federal budget deficit (to the nominal

GDP, expressed as a percent;

$\operatorname{AR}(1)=$ the autoregressive term.

All of the explanatory variables are annual and are unlagged. The specifications in equations

(5) and (6) adopt two alternative forms of the federal budget deficit, namely, the total 
(unified) budget deficit (DEFY) and the primary budget deficit (PRIMARYDEFY), respectively, where the latter excludes net interest payments on the national debt (Burda and Wyplosz, 1995).4 The budget deficit variables, the M2 money supply variable, and net capital inflows variable are all scaled by GDP because the size of each of these variables should be judged relative to the size of the economy (Ostrosky, 1990; Cebula, 2014). The study period ranges from 1973 through 2016.

The dependent variable in both versions, i.e., equations (5) and (6), of this system, EPRTHIRTY, is contemporaneous with all seven of the explanatory variables, namely, DEFY or PRIMARYDEFY, (M2/Y), (NCI/Y), EPRTHREE, EPRTXFR, TAXRATE, and Y. Given these contemporaneous components in this specification, the possibility of simultaneity bias arises, which in turn mandates the choosing of instrumental variables and then estimating by 2SLS (two-stage least squares). The instruments chosen for the contemporaneous explanatory variables found in equations (5) and (6) are the two-year lags of each of the explanatory variables, along with a measure of income tax evasion (lagged two years) as a second instrument for the budget deficit, reflecting the complexity of its determinants. 5 The data for the variables in this analysis were obtained from Federal Reserve Bank of St. Louis (2017), Ledbetter (2004, 2007), Foertsch (2016), and the Council of Economic Advisors (2017, Tables B-1, B-10, B-11, B-18, B-25). The descriptive statistics (means, standard deviations, maxima, and minima) for the variables in the model are found in Table 2.

Table 2. Descriptive Statistics

\begin{tabular}{|l||c|c|c|c|}
\hline Variable & Minimum & Mean & $\begin{array}{l}\text { Standard } \\
\text { Deviation }\end{array}$ & Maximum \\
\hline \hline EPRTHIRTY & -4.35 & 2.918 & 2.719 & 8.96 \\
\hline DEFY & -2.3 & 3.016 & 2.44 & 9.8 \\
\hline$\Delta(M 2 / Y)$ & -5.644 & 2.542 & 11.1 & 57 \\
\hline NCI/Y & -0.832 & 2.191 & 1.693 & 5.725 \\
\hline EPRTHREE & -4.46 & 1.797 & 2.903 & 9.13 \\
\hline EPRTXFR & -5.477 & 2.034 & 2.654 & 6.283 \\
\hline$Y$ & -2.8 & 2.787 & 2.063 & 7.3 \\
\hline TAXRATE & 28 & 45.478 & 14.808 & 77 \\
\hline PRIMARYDEFY & -4.7 & 0.884 & 2.7092 & 9.4 \\
\hline
\end{tabular}

\footnotetext{
${ }^{4}$ For year $t$, the primary deficit is government spending minus tax revenue for the year; the total deficit for that year is the primary deficit plus the interest paid on the national debt in the previous year.

${ }^{5}$ The tax evasion measure is the AGI Gap, the ratio of unreported adjusted gross income to actual adjusted gross income.
} 


\section{Empirical Results}

Based fundamentally on the model presented above in equation (4), two different estimation techniques are adopted in order to establish consistency of the key findings, i.e., those regarding the budget deficit and the tax rate variables. The econometric approaches to be adopted are, as follows: the autoregressive two stage least squares (AR/2SLS) technique, found in sub-section $4 \mathrm{a}$ (Tables 3 and 4), and the ML_ARCH technique, found in sub-section $4 \mathrm{~b}$ (Tables 5 and 6).

\subsection{Autoregressive Two Stage Least Squares Estimations}

The AR/2SLS estimation provided in this study involves the autoregressive process AR(1), which is of interest and relevance as a process having many times-series applications, perhaps being best applicable to time series that exhibit more volatile behavior, such as stock market indices, stock prices, and, as is the focus in the present study, interest rates (Greene,2012; Hair, et al., 2006).

Naturally, in the ML-ARCH estimation provided in the following sub-section of this study, the AR(1) term is omitted.

In any case, adopting the Newey and West (1987) heteroscedasticity correction, the AR/2SLS estimate of equation (5) is provided in Table 3, where estimated coefficients, standard errors, t-values, and values for "prob." are all provided for each of the seven explanatory variables.

Table 3. AR/2SLS Estimation Results: DEFY Case. Dependent Variable: EPRTHIRTY

\begin{tabular}{|l||c|c|c|c|}
\hline Variable & Coefficient & St. Error & t-value & Prob. \\
\hline \hline DEFY & $0.086^{* * *}$ & 0.0242 & 3.57 & 0.0011 \\
\hline$\Delta(\mathrm{M} 2 / \mathrm{Y})$ & $-0.125^{* * *}$ & 0.0419 & -2.97 & 0.0055 \\
\hline $\mathrm{NCI} / \mathrm{Y}$ & 0.24 & 3.7100 & 0.07 & 0.9485 \\
\hline EPRTHREE & $0.386^{* * *}$ & 0.0513 & 7.52 & 0.0000 \\
\hline EPRTXFR & $0.591^{* * *}$ & 0.0569 & 10.4 & 0.0000 \\
\hline TAXRATE & $0.013^{* *}$ & 0.0057 & 2.19 & 0.0355 \\
\hline $\mathrm{Y}$ & $0.067^{*}$ & 0.0347 & 1.94 & 0.0612 \\
\hline Constant & 0.007 & 0.3055 & 0.02 & 0.9817 \\
\hline
\end{tabular}

$\begin{array}{ll}\text { AR (1) } & -0.0457 \\ \text { Inverted Root } & -0.05 \\ \text { Instrument Rank } & 17 \\ \text { J-Statistic } & 14.21 * \\ \mathrm{~N}=43 & \end{array}$

*** Statistically significant at the $1 \%$ level; **statistically significant at the $2.5 \%$ level; *statistically significant at the $10 \%$ level. 
In Table 3, six of the seven estimated coefficients on the explanatory variables are shown to exhibit the expected signs, with four being statistically significant at the $1 \%$ level, one being significant at beyond the $5 \%$ level, and one being significant at beyond the $7 \%$ level. The inverted root is -0.05 , so that this estimation involves a stationary autoregressive process. The instrument rank of 17 attests favorably to the efficacy of the instrumental variables. For the interested reader, multicollinearity is not an issue in this analysis. Finally, the J-Statistic is statistically significant at beyond the $8 \%$ level, implying that the instruments are exogenous.

Thus, the autoregressive two-stage least squares estimation that is summarized in Table 3 provides strong evidence that the ex post real average interest rate yield on thirty-year U.S. Treasury bonds is a decreasing function (at the $1 \%$ statistical significance level) of the ratio of the M2 money supply to the GDP level, while being (at the $1 \%$ statistical significance level) an increasing function of the ex post real interest rate yields on three-year Treasury notes and tax-free high grade municipal bonds.

These "control variable" results notwithstanding, of greatest interest from the perspective of this study are the findings regarding the budget deficit and income tax rate variables. In the case of the first of these two key variables, the estimated coefficient on the total federal budget deficit variable, $D E F Y$, is positive, as hypothesized, and statistically significant at the $1 \%$ level. Thus, the higher the total federal budget deficit (as a percent of GDP), the higher the ex post real interest rate yield on thirty-year Treasury bonds. This finding is consistent in principle with a variety of empirical studies of earlier periods regarding intermediate- to longterm interest rate yields, including studies by Al-Saji (1993), Cebula (2013), Hoelscher (1986), Cebula and Saltz (1998), Tanzi (1985), and Zahid (1988), among others. In the case of the second of these two key variables, the estimated coefficient on the tax rate variable TAXRATE is also positive, as hypothesized, and statistically significant at nearly the $4 \%$ level. Thus, raising the maximum marginal federal personal income tax rate would also have the effect of raising the real interest rate yield on thirty-year Treasury bonds. Conversely, a cut in this tax rate would reduce this thirty-year interest rate yield.

Next, adopting the Newey and West (1987) heteroscedasticity correction, the AR/2SLS estimate of equation (6), where the primary deficit replaces the total deficit, is provided in Table 4, where coefficients, standard errors, t-values, and values for "prob." are once again all provided. In Table 4, all seven of the estimated coefficients on the explanatory variables exhibit the expected signs, with four being statistically significant at the $1 \%$ level and one being statistically significant at the $2.5 \%$ level. These results closely parallel those in Table 3 . The inverted root is -0.18 , so that this estimation also involves a stationary autoregressive process. The instrument rank of 17 attests favorably regarding the efficacy of the instrumental variables. Moreover, the J-Statistic is found to be statistically significant at beyond the $8 \%$ level, implying that the instruments are found to be exogenous. 
CEBULA Budget Deficits, Tax Rates and Ex-Post Real Interest Rate

Table 4. AR/2SLS Estimation Results: Primary Deficit Case. Dependent Variable: EPRTHIRTY

\begin{tabular}{|l||c|c|c|c|}
\hline Variable & Coefficient & St. Error & t-value & Prob. \\
\hline \hline PRIMARYDEFY & $0.068^{* * *}$ & 0.0186 & 3.63 & 0.0010 \\
\hline$\Delta(\mathrm{M} 2 / \mathrm{Y})$ & $-0.141^{* * *}$ & 0.0514 & -2.74 & 0.0099 \\
\hline $\mathrm{NCI} / \mathrm{Y}$ & -0.0038 & 0.3937 & -0.10 & 0.9246 \\
\hline EPRTHREE & $0.358^{* * *}$ & 0.0492 & 7.29 & 0.0000 \\
\hline EPRTXFR & $0.642^{* * *}$ & 0.0612 & 10.50 & 0.0000 \\
\hline TAXRATE & $0.015^{* *}$ & 0.0067 & 2.50 & 0.0189 \\
\hline Y & 0.063 & 0.0382 & 1.64 & 0.1107 \\
\hline Constant & 0.068 & 0.3236 & 0.21 & 0.8359 \\
\hline
\end{tabular}

$\begin{array}{ll}\text { AR (1) } & -0.181 \\ \text { Inverted Root } & -0.18 \\ \text { Instrument Rank } & 17\end{array}$

$* * *$ Statistically significant at the $1 \%$ level; ** at the $2.5 \%$ level; $*$ at the $10 \%$ level.

Hence, the autoregressive two-stage least squares estimation summarized in Table 4 provides strong evidence that the real average interest rate yield on thirty-year U.S. Treasury bonds is a decreasing function (at the 1\% statistical significance level) of the ratio of the M2 money supply to the GDP level, while being an increasing function (at the 1\% statistical significance level) of both the real interest rate yields on three-year Treasury notes and tax-free high grade municipals.

These "control variable" results notwithstanding, of greater interest are the AR/2SLS findings for the budget deficit and income tax rate variables. In the case of the first of these two variables, the estimated coefficient on the primary federal budget deficit variable, PRIMARYDEFY, is positive, as hypothesized, and statistically significant at the $1 \%$ level. Thus, the higher the primary budget deficit (as a percent of GDP), the higher the ex post real interest rate yield on thirty-year Treasury bonds. This finding is consistent in principle with a variety of empirical studies of earlier periods regarding the total budget deficit and other intermediate- to long-term typically nominal interest rate yields. In the case of the second of the central variables under analysis in this study, the estimated coefficient on the tax rate variable, TAXRATE is also positive, as hypothesized, and statistically significant at the $2 \%$ level. Thus, as was inferred from the results shown in Table 3, raising the maximum marginal federal personal income tax rate would have the effect of increasing the real interest rate yield on thirty-year Treasury bonds, whereas a cut in this tax rate would reduce this thirty-year interest rate yield. 


\subsection{ML_ARCH Estimations}

Based on equation (5), the first ML_ARCH estimation is provided in Table 5, with $z$-statistics "replacing" the $t$-values found among the findings. As shown, all of the seven estimated coefficients exhibit the hypothesized sign, with five of these being statistically significant at the $1 \%$ level and one being statistically significant at the $6 \%$ level. Except for the case of the variable $Y_{t}$, these results parallel those in the AR/2SLS estimates found in Tables 3 and 4.

Table 5. ML_ARCH Estimation Results, 1973-2016-Normal (Gaussian) Distribution, DEFY Case; Dependent Variable: EPRTHIRTY

\begin{tabular}{|l||l|r|r|l|}
\hline Variable & Coefficient & St. Error & z-statistic & Prob \\
\hline \hline DEFY & $0.082^{* * *}$ & 0.0156 & 5.25 & 0.0000 \\
\hline$\Delta(\mathrm{M} 2 / \mathrm{Y})$ & $-0.045^{*}$ & 0.0235 & -1.91 & 0.0564 \\
\hline $\mathrm{NCI} / \mathrm{Y}$ & -0.021 & 0.0257 & -0.81 & 0.4161 \\
\hline EPRTHREE & $0.41^{* * *}$ & 0.0278 & 14.7 & 0.0000 \\
\hline EPRTXFR & $0.555^{* * *}$ & 0.0295 & 18.82 & 0.0000 \\
\hline TAXRATE & $0.011^{* * *}$ & 0.0033 & 3.28 & 0.0010 \\
\hline Y & $0.067^{* * *}$ & 0.0174 & 3.87 & 0.0001 \\
\hline Constant & 0.104 & 0.1629 & 0.64 & 0.5248 \\
\hline
\end{tabular}

VARIANCE EQUATION

\begin{tabular}{|l||l|l|r|l|}
\hline Constant & $0.078^{*}$ & 0.0400 & 1.96 & 0.0499 \\
\hline RESID $(-1)^{2}$ & 0.669 & 0.4872 & 1.37 & 0.1696 \\
\hline GARCH & $-0.968^{* * *}$ & 0.2215 & -4.37 & 0.0000 \\
\hline
\end{tabular}

$\mathrm{R}^{2}=0.99$

Adj $R^{2}=0.98$

***Statistically significant at the $1 \%$ level; ** statistically significant at the $2.5 \%$ level; *statistically significant at the $10 \%$ level.

Thus, these results imply that EPRTHIRTY is, at the $1 \%$ statistical significance level an increasing function of EPRTHREE, EPRTXFR, and $Y$. Within the context of the present study, of greatest salience are the estimated coefficients on the variables TAXRATE and DEFY, both of which are positive, as hypothesized, and statistically significant at the $1 \%$ level. These two results are econometrically compatible with their counterparts in Table 3, implying once again that the ex post real interest rate yield on thirty-year Treasuries is an increasing function of 
both the total federal budget deficit (expressed as a percent of GDP) and the maximum marginal federal personal income tax rate.

Based on equation (6), the second ML_ARCH estimation is provided in Table 6. As shown, all seven estimated coefficients exhibit the hypothesized sign, with four of these being statistically significant at the $1 \%$ level and one being statistically significant at the $2.5 \%$ level. Except for the variables $\Delta(\mathrm{M} 2 / \mathrm{Y})$ and $\mathrm{Y}_{\mathrm{t}}$, these results closely parallel those in the AR/2SLS estimates found in Tables 3 and 4. Accordingly, the results in Table 6 imply that EPRTHIRTY is, at the $1 \%$ statistical significance level an increasing function of EPRTHREE and EPTTXFE, and, at the $2.5 \%$ level, an increasing function of $Y$. The estimated coefficients on the variables TAXRATE as well; as PRIMARYDEFY, are positive, as hypothesized, and statistically significant at the $1 \%$ level. These two results are econometrically compatible with their counterparts in Table 3, implying once again that the ex post real interest rate yield on thirty-year Treasuries is an increasing function of both the primary federal budget deficit (expressed as a percent of GDP) and the maximum marginal federal personal income tax rate.

Table 6. ML_ARCH Estimation Results, 1973-2015-Normal Distribution: PRIMARYDEFY Case. Dependent Variable: EPRTHIRTY

\begin{tabular}{|l||l|c|c|l|}
\hline Variable & Coefficient & St. Error & z-statistic & Prob \\
\hline \hline PRIMARYDEFY & $0.086^{* * *}$ & 0.0183 & 4.71 & 0.0000 \\
\hline$\Delta(\mathrm{M} 2 / \mathrm{Y})$ & -0.032 & 0.0272 & -1.20 & 0.2319 \\
\hline $\mathrm{NCI} / \mathrm{Y}$ & -0.018 & 0.0205 & -0.86 & 0.3882 \\
\hline EPRTHREE & $0.424 * * *$ & 0.0301 & 14.10 & 0.0000 \\
\hline EPRTXFR & $0.544^{* * *}$ & 0.0285 & 19.09 & 0.0000 \\
\hline TAXRATE & $0.0094^{* * *}$ & 0.0029 & 3.24 & 0.0012 \\
\hline Y & $0.0567^{* *}$ & 0.0244 & 2.32 & 0.0203 \\
\hline Constant & 0.349 & 0.1155 & 3.03 & 0.0025 \\
\hline
\end{tabular}

VARIANCE EQUATION

\begin{tabular}{|l||l|l|r|l|}
\hline Constant & 0.061 & 0.0417 & 1.47 & 0.1412 \\
\hline RESID $(-1)^{2}$ & $0.881^{*}$ & 0.5325 & 1.66 & 0.0977 \\
\hline GARCH & -0.5396 & 0.4402 & -1.23 & 0.2203 \\
\hline
\end{tabular}

$\mathrm{R}^{2}=0.99$

Adj $R^{2}=0.98$

***Statistically significant at the $1 \%$ level; **statistically significant at the $2.5 \%$ level;

*statistically significant at the $10 \%$ level 


\section{Concluding Observations}

This empirical study adopts an open loanable funds model to investigate the impacts of both federal government budget deficits and federal personal income tax rates on the ex post real interest rate yield on thirty-year U.S. Treasury bonds, with various financial-market and economic control variables included in the analysis as well. It is noteworthy that very little emphasis in the scholarly literature published during the last 20 years has been placed on determinants of this ex post real interest rate yield. In any case, the AR/2SLS and ML_ARCH estimates involving the 1973-2016 study period all imply that the ex post real interest rate yield on thirty-year U.S. Treasury bonds has been a statistically significant increasing function of both the federal budget deficit (both the total/unified deficit and the primary deficit) expressed as a percent of GDP and the maximum marginal federal personal income tax rate. Interestingly, this finding for the budget deficit is consistent in with the findings in a variety of empirical studies of earlier periods regarding intermediate- to long-term typically interest rate yields, including those by Al-Saji (1993, Cebula (2013, 2014), Choi and Holmes (2014), Ewing and Yanochik (1999), Findlay (1990), Gale and Orszag (2003), Gissey (1999), Hoelscher (1986), Johnson (1992), Cebula and Saltz (1998), Tanzi (1985), and Zahid (1988).

It is observed in closing that factors elevating the federal budget deficit will clearly act, in the absence of segmented markets, to raise the real cost of borrowing across the U.S., ceteris paribus. In addition, when lawmakers elevate the maximum marginal personal tax rate, the real cost of borrowing across the U.S. is also going to be elevated, ceteris paribus. Given the time period studied, these relationships appear to be both resilient and current ones that policy-makers should not overlook. Moreover, over the long run, failure to address the federal budget deficit issue and/or enacting statutory increases in the federal personal income tax rate could have profound negative impacts on the finances of firms, households, and state and local governments and hence on the pace of capital formation and the long-term growth of the macro-economy. Based upon the findings in this empirical study, limiting the size of the budget deficit and lowering federal personal income tax rates would act to reduce upwards pressure on the real interest rate yield on thirty-year Treasury bonds and consequently act through the financial markets to stimulate economic expansion. Naturally, the findings obtained in this study cannot be regarded as definitive; further research on the topic is clearly necessary.

\section{References}

Allison, P.D. (1999). Multiple Regression: A Primer. Thousand Oaks, CA: Pine Forge Press. Al-Saji, A. (1993) Government budget deficits, nominal and ex post real long term interest rates in the U.K., 1960.1-1990.2. Atlantic Economic Journal 21: 71-77. 
Burda, M. and Wyplosz, C. (1995). European Macroeconomics, 2nd ed., Oxford: OxfordUniversity Press.

Carlson, K.M., and Spencer, R.W. (1975) Crowding out and its critics. Federal Reserve Bank St. Louis Review 57: 1-19.

Cebula, R.J. (2013) An exploratory inquiry into the impact of budget deficits on the nominal interest rate yield on Moody's Aaa-rated corporate bonds, Applied Economics Letters,20: 1497-1500.

Cebula, R.J. (2014). Impact of federal government budget deficits on the longer-term ex post real interest rate in the U.S.: Evidence using annual and quarterly data, 1960-2013, Applied Economics Quarterly, 60: 23-40.

Cebula, R.J., and Saltz, I.S. (1998) Ex post real long-term interest rates and U.S. federal budget deficits: Preliminary error-correction evidence, 1971-1991. Economia Internazionale 51: 163-169.

Cebula, R.J., Angjellari-Dajci, F., and Foley, M. (2014). An exploratory empirical inquiry into theimpact of federal budget deficits on the ex post real interest rate yield on ten year Treasury notes over the last half century, Journal of Economics and Finance, 38: 712-720.

Choi, D.F.S., and Holmes, M.J. (2014). Budget deficits and real interest rates: a regime-switching reflection on Ricardian Equivalence. Journal of Economics and Finance, 38: 71-83.

Cecchetti, S. G. (2006). Money, Banking and Financial Markets. New York: McGraw-HillIrwin.

Council of Economic Advisors. (2017). Economic report of the president, 2017. Washington, D.C: U.S. Government Printing Office.

Ewing, B.T., and Yanochik, M.A. (1999) Budget deficits and the term structure of interest rates in Italy. Applied Economics Letters 6: 199-201.

Federal Reserve Bank of St. Louis. (2017). Economic research At: https://fred.stlouisfed.org/ Findlay, D.W. (1990) Budget deficits, expected inflation, and short-term real interest rates. International Economic Journal, 4: 41-53.

Foertsch, T. (2016). The Department of the Treasury, Office of Tax Analysis. Using a Reconciliation of NIPA Personal Income and IRS AGI to Analyze Tax Expenditures, At: https://www.treasury.gov/resource-center/tax-policy/tax-analysis/Documents/WP-109.pdf

Gale, W.G., and Orszag, P.R. (2003). Economic effects of sustained budget deficits. National Tax Journal, 49: 151-164.

Gissey, W. (1999) Net Treasury borrowing and interest rate changes. Journal of Economics and Finance, 23: 211-219.

Greene, W. H. (2012), Econometric Analysis (Sixth edition). Upper Saddle River: Pearson.

Hair, J.F., Anderson, R. Tatham, R.L., and Black, W.C. (2006). Multi-variate data Analysis. Upper Saddle River, NJ: Prentice-Hall. 
Hoelscher, G. (1983) Federal borrowing and short-term interest rates. Southern Economic Journal, 50: 319-333.

Hoelscher, G. (1986) New evidence on deficits and interest rates. Journal of Money, Credit and Banking 18: 1-17.

Johnson, C.F. (1992) An empirical note on interest rate equations. Quarterly Review of Economics and Finance, 32: 141-147.

Koch, J.V. (1994) Federal budget deficits, interest rates, and international capital flows: A further note, Quarterly Review of Economics and Finance, 32: 117-120.

Ledbetter, M. (2004). A comparison of BEA estimates of personal income and IRS estimates of adjusted gross income. Survey of Current Business, 84(4), 8-22.

Ledbetter, M. (2007). Comparison of BEA Estimates of Personal Income and and IRS Estimates of Adjusted Gross Income. Survey of Current Business, 87, 35-41.

Madura, J. (2008). Financial Markets and Institutions. Mason, OH: Thompson Higher Learning.

Newey W.K., and West K.D. (1987) A simple positive semi-definite, heteroscedasticity and autocorrelation consistent covariance matrix. Econometrica 55: pp. 703-708.

Ostrosky, A.L. (1990) Federal budget deficits and interest rates: Comment. Southern Economic Journal, 56: 802-803.

Swamy, P.A.V.B., Kolluri, B.R., and Singamsetti, R.N. (1992) What do regressions of interest rates on deficits imply? Southern Economic Journal 56: 1010-1028.

Tanzi, V (1985) Fiscal deficits and interest rates in the United States. I.M.F. Staff Papers, 33: 551-576.

Wooldridge, J. M. (2002). Econometric Analysis of Cross Section and Panel Data. Cambridge, MA: The MIT Press.

Zahid, K (1988) Government budget deficits and interest rates: The evidence since 1971 using alternative deficit measures. Southern Economic Journal, 54: 725-731. 